\title{
Technological Ecosystems
}

\author{
Francisco José García-Peñalvo \\ Research Institute for Educational Sciences (IUCE), GRIAL Research Group, University of \\ Salamanca. Paseo de Canalejas 169, 37008, Salamanca, Spain (email fgarcia@usal.es)
}

\begin{abstract}
The challenges and issues of the Knowledge Society require complex technological systems that may evolve and interoperate with each other. This complexity means to reorganize these systems as a set of components that may offer services, interact and evolve in very different ways including capabilities such as adaptation and intelligent behaviors. Also, the users should be considered as other important components of these so-called technological ecosystems. The Technological Ecosystems for Enhancing Multiculturality - TEEM Conference is an event that studies the most significant advances in this research area, in which the Engineering approach is always a key factor. From the last edition of this event, TEEM 2014, that was held in the University of Salamanca in October 1-3, 2014, seven papers were selected that have been extended and reviewed again. Three of these papers were finally accepted for publication in VAEP-RITA / IEEE RITA journal.
\end{abstract}

Index Terms- TEEM; Technological Ecosystems; Engineering; Knowledge Society

\section{INTRODUCTION}

$\mathrm{B}^{\mathrm{e}}$ eyond fashion trends in technology, the fact is that in institutions large software applications collections coexist, both commercial and open source, which require integration and interoperability to support its effective functioning in the corporate context $[1,2]$. When the integration degree of these components is high, symbiotic relationships appear between them. Therefore, it is mandatory to attend both the evolution needs of each separate component and the influences of their evolution in the corporate context, including the users as other component too. This way, a high complexity technological ecosystem arises [3, 4].

This technological metaphor is derived from the concept of biological ecosystem as a community of living beings whose life processes are interrelated and whose development is based on the physical factors of the environment they are living in. When one tries to move this biological meaning to a technological context there are multiple definitions with different perspectives, but all of them converge in a fundamental point: there is a clear relationship between a natural ecosystem and a technological ecosystem characteristics, independently of their multiple conceptions [57].

This approach has great importance to face the challenges and problems related to the Digital Society that are growing with the Knowledge Society that we all desire to achieve [8, 9]. In these issues an advanced knowledge management supported by complex technological ecosystems is one of the architectural layers of the current information systems in corporations [10], due to the fact that successful knowledge management is one of the main challenges for any kind of organization [11].

The definition of an architectural framework for technological ecosystems needs to take into consideration all aspects related to integration, interoperability and evolution of the components, as well as an appropriate definition of the underlying architecture [12].

The current state and technical evolution of digital learning ecosystems runs parallel to Internet and cloud-based services. A good example of this correspondence is the trend towards data retrieval and analysis oriented to decision-making [13].

On the other hand, the complexity of the faced problems needs multidisciplinary and multicultural solutions [14].

Consistently with this approach the International TEEM Conference (Technological Ecosystems for Enhancing Multiculturality - http://teemconference.eu/) takes place, of which two editions have already been held, TEEM 2013 [15, 16] and TEEM 2014 [17].

Engineering solutions are fully required to tackle these technological ecosystems, thus IEEE RITA journal has always supported the TEEM Conference with special sections [9, 1821].

In order to configure this special section of IEEE RITA seven papers were selected from the TEEM 2014 edition. These were extended and reviewed again. Finally, only three of them were selected for publication.

In the first paper Navarro et al. present an evaluation framework for mLearning applications, considering both pedagogical usability and user interface usability [22, 23]. This work is based on an analysis of the mLearning [24] and usability [25] research lines.

Joo Nagata et al. intend to establish the relationships between local heritage educational content of Mobile Pedestrian Navigation Systems -Augmented Reality software and learning processes through mobile devices [26, 27]. This paper is focused on the development of a technological ecosystem that allows ubiquitous learning or uLearning [28] in order to maximize the learning outcomes in comparison with other direct learning methods [29]. 
The last paper presents a summary of the firsts results of the VALS (Virtual Alliances for Learning Society) European Project [30-32] about the experiences of Computer Engineering students performing virtual placements in open software companies all around the world [33, 34].

\section{ACKNOWLEDGEMENTS}

I want to thank IEEE RITA and its Editor-in-Chief, Dr. Martín Llamas Nistal, for the support received in the events that this paper relates.

I would also like to thank the authors of the selected papers for the effort to extend and improve their papers introducing the comments made by the referees, attendants and session chairs. These greetings are also for the international board of reviewers.

\section{REFERENCES}

[4] A. García-Holgado and F. J. García-Peñalvo, "Architectural pattern for the definition of eLearning ecosystems based on Open Source developments," in Proceedings of 2014 International Symposium on Computers in Education (SIIE), Logrono, La Rioja, Spain, 1214 Nov. 2014, J. L. Sierra-Rodríguez, J.M. Dodero-Beardo, and D. Burgos, Eds., ed USA: Institute of Electrical and Electronics Engineers, 2014, pp. 93-98.

[5] M. Berthelemy, "Definition of a learning ecesystem,"/in Learning Conversations. Thoughts, ideas and Yeflections from Mark Berthelemy vol. 2015, ed, 2013.

[6] E. Chang and M. West, "Digital Ecosystems A Next Generation of the Collaborative Environment," in Proceedings of iiWAS'2006 The Eighth International Conference on Information Integration and Web-based Applications Services, 4-6 December 2006, Yogyakarta, Indonesia, G. Kotsis, D. Taniar, E. Pardede, and I. K. Ibrahim, Eds., ed: Austrian Computer Society, 2006, pp. 3-24.

[7] M. Laanpere, "Digital Learning ecosystems: rethinking virtual learning environments in the age of social media," presented at the IFIP-OST'12: Open and Social Technologies for Networked Learning, Taillinn, Estonia, 2012.

[8] F. J. García-Peñalvo, "Managing the Knowledge Society Construction," International Journal of Knowledge Management, vol. 10, pp. iv-vii, 2014.

[9] F. J. García-Peñalvo, "Engineering contributions into a Knowledge Society multicultural perspective," IEEE Revista Iberoamericana de Tecnologías del Aprendizaje (IEEE RITA), vol. 10, pp. 17-18, 2015.

[10] Á. Fidalgo-Blanco, M. L. Sein-Echaluce, and F. J. García-Peñalvo, "Knowledge Spirals in Higher Education Teaching Innovation," International Journal of Knowledge Management, vol. 10, pp. 1637, 2014.

[11] A. García-Holgado, F. J. García-Peñalvo, Á. Hernández-García, and F. Llorens-Largo, "Analysis and Improvement of Knowledge Management Processes in Organizations Using the Business Process Model Notation," in New Information and Communication
Technologies for Knowledge Management in Organizations. 5th Global Innovation and Knowledge Academy Conference, GIKA 2015, Valencia, Spain, July 14-16, 2015, Proceedings, D. PalaciosMarqués, D. Ribeiro Soriano, and K. H. Huarng, Eds., ed Switzerland: Springer International Publishing, 2015, pp. 93-101.

[12] F. J. García-Peñalvo, M. A. Conde, M. Alier, and M. J. Casany, "Opening Learning Management Systems to Personal Learning Environments," Journal of Universal Computer Science, vol. 17, pp. 1222-1240, 2011.

[13] F. J. García-Peñalvo, Á. Hernández-García, M. Á. CondeGonzález, Á. Fidalgo-Blanco, M. L. Sein-Echaluce Lacleta, M. Alier-Forment, et al., "Learning services-based technological ecosystems.," in Proceedings of the Third International Conference on Technological Ecosystems for Enhancing Multiculturality (TEEM'15) (Porto, Portugal, October 7-9, 2015), ed New York, USA: ACM, 2015.

[14] F. J. García-Peñalvo, Multiculturalism in Technology-Based Education: Case Studies on ICT-Supported Approaches. Hershey, PA, USA: Information Science Reference, 2013.

[15] F. J. García-Peñalvo, A. García-Holgado, and J. Cruz-Benito, Proceedings of the TEEM'13 Track on Knowledge Society Related Projects. Salamanca, Spain: Grupo GRIAL, 2013.

[16] F. J. García-Peñalvo, Proceedings of the First International Conference on Technological Ecosystems for Enhancing Multiculturality, TEEM 2013. New York, USA: ACM, 2013.

[17] F. J. García-Peñalvo, Proceedings of the Second International Conference on Technological Ecosystems for Enhancing Multiculturality, TEEM 2014. New York, USA: ACM, 2014.

[18] F. J. García-Peñalvo, "Aportaciones de la Ingeniería en una Perspectiva Multicultural de la Sociedad del Conocimiento," VAEP-RITA, vol. 1, pp. 201-202, 2013.

[19] F. J. García-Peñalvo, A. Sarasa Cabezuelo, and J. L. Sierra Rodríguez, "Innovando en los Procesos de Ingeniería. Ingeniería como Medio de Innovación," VAEP-RITA, vol. 2, pp. 26-28, 2014. F. J. García-Peñalvo, A. Sarasa Cabezuelo, and J. L. Sierra González, "Innovating in the Engineering Processes: Engineering as a Means of Innovation," IEEE Revista Iberoamericana de Tecnologías del Aprendizaje (IEEE RITA), vol. 9, pp. 131-132, 2014.

F. J. García-Peñalvo, "Ecosistemas Tecnológicos," IEEE VAEP-

RITA, vol. 3, pp. 36-37, 2015.
[22] C. X. Navarro, A. I. Molina, M. Á. Redondo, and R. JuárezRamírez, "Framework to Evaluate M-learning Systems: a Technological and Pedagogical Approach," IEEE Revista Iberoamericana de Tecnologías del Aprendizaje (IEEE RITA), 2015.

[23] C. X. Navarro, A. I. Molina, M. Á. Redondo, and R. JuárezRamírez, "Framework para Evaluar Sistemas M-learning: Un Enfoque Tecnológico y Pedagógico," VAEP-RITA, vol. 3, pp. 3845, 2015.

[24] J. C. Sánchez Prieto, S. Olmos Migueláñez, and F. J. GarcíaPeñalvo, "Understanding mobile learning: devices, pedagogical implications and research lines," Education in the Knowledge Society, vol. 15, pp. 20-42, 2014.

[25] J. Nielsen and R. Budiu, Usabilidad en dispositivos móviles. Madrid: Anaya Multimedia, 2013.

[26] J. Joo Nagata, J. R. García-Bermejo Giner, and F. Martínez Abad, "Patrimonio Virtual del Territorio: Diseño e implementación de Recursos Educativos en Realidad Aumentada y Navegación Peatonal Móvil," VAEP-RITA, vol. 3, pp. 46-51, 2015.

[27] J. Joo Nagata, J. R. García-Bermejo Giner, and F. Martínez Abad, "Virtual Heritage of the Territory: Design and Implementation of Educational Resources in Augmented Reality and Mobile Pedestrian Navigation," IEEE Revista Iberoamericana de Tecnologías del Aprendizaje (IEEE RITA), 2015.

[28] M. Á. Conde González, C. Muñoz Martín, and F. J. GarcíaPeñalvo, "M-learning, towards U-learning," in Proceedings of the IADIS International Conference Mobile Learning 2008. (April 1113, 2008, Algarve, Portugal). I. Arnedillo Sánchez and P. Isaías, Eds., ed Portugal: IADIS Press, 2008, pp. 196-200.

[29] J. R. Anderson, L. M. Reder, and H. A. Simon, "Situated Learning and Education," Educational Researcher, vol. 25, pp. 5-11, 1996.

[30] F. J. García-Peñalvo, J. Cruz-Benito, M. Á. Conde, and D. Griffiths, "Virtual placements for informatics students in open source business across Europe," in 2014 IEEE Frontiers in 
Education Conference Proceedings (October 22-25, 2014 Madrid, Spain), ed USA: IEEE, 2014, pp. 2551-2555.

[31] F. J. García-Peñalvo, J. Cruz-Benito, D. Griffiths, P. Sharples, S. Willson, M. Johnson, et al., "Developing Win-Win Solutions for Virtual Placements in Informatics: The VALS Case," in Proceedings of the Second International Conference on Technological Ecosystem for Enhancing Multiculturality (TEEM'14), F. J. García-Peñalvo, Ed., ed New York, USA: ACM, 2014, pp. 733-738.

[32] F. J. García-Peñalvo, J. Cruz-Benito, M. Á. Conde, and D. Griffiths, "Semester of Code: Piloting Virtual Placements for Informatics across Europe," in Proceedings of Global Engineering Education Conference, EDUCON 2015. Tallinn, Estonia, 18-20 Mach 20015, ed USA: IEEE, 2015, pp. 567-576.

[33] F. J. García-Peñalvo, J. Cruz-Benito, D. Griffiths, and A. P. Achilleos, "Tecnología al servicio de un proceso de gestión de prácticas virtuales en empresas: Propuesta y primeros resultados del Semester of Code," IEEE VAEP-RITA, vol. 3, pp. 52-59, 2015.

[34] F. J. García-Peñalvo, J. Cruz-Benito, D. Griffiths, and A. P. Achilleos, "Virtual placements management process supported by technology: Proposal and firsts results of the Semester of Code," IEEE Revista Iberoamericana de Tecnologías del Aprendizaje (IEEE RITA), 2015.

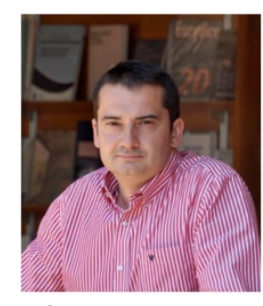

Francisco José García-Peñalvo completed his undergraduate studies in Computing at the University of Salamanca and University of Valladolid and his Ph.D. at the University of Salamanca. Dr. García-Peñalvo is the head of the research group GRIAL (Research Group Interaction and eLearning). His main research interests focus on eLearning, Computers \& Education, Adaptive Systems, Web Engineering, Semantic Web and Software Reuse. He has led and participated in over 50 research and innovation projects. He was Vice Chancellor for Innovation at the University of Salamanca between March 2007 and December 2009. He has published more than 300 articles in international journals and conferences. He has been guest editor of several special issues of international journals (Online Information Review, Computers in Human Behaviour, Interactive Learning Environments...). He is also a member of the program committee of several international conferences and reviewer for several international journals. At present, he is the Editor-in-Chief of the International Journal of Information Technology Research and the Education in the Knowledge Society Journal. Besides, he is the coordinator of the multidisciplinary PhD Programme on Education in the Knowledge Society.

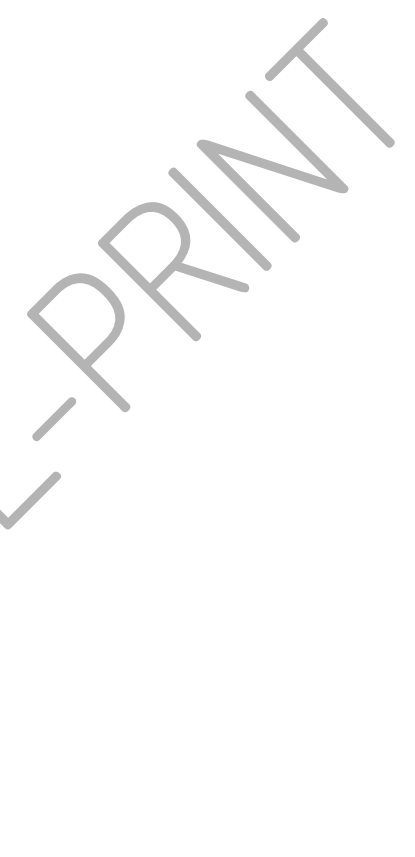

